\title{
O SURGIMENTO DO CORÃO EM MEIO A GUERRAS POR JESUS
}

\author{
PEDRO LIMA VASCONCELLOS \\ UNIVERSIDADE FEDERAL DE ALAGOAS. Brasil
}

Resumo: O artigo problematiza a visão, oriunda da tradição muçulmana e assumida por grande parte da pesquisa acadêmica, sobre as origens do Corão. E sugere tomá-lo como testemunha insubstituível de dinâmicas sociorreligiosas do Oriente Médio, particularmente processos vividos pelo cristianismo dos séculos V-VII, marcado por grupos diferenciados em conflito e pela circulação de memórias e tradições sobre Jesus não necessariamente ancoradas no Novo Testamento.

Palavras-chave: Corão, Jesus, Apócrifos, Cristianismo antigo, Sura 19.

\section{LA EMERGENCIA DEL CORÁN EN MEDIO DE GUERRAS POR JESÚS}

Resumen: El artículo cuestiona la visión tradicional musulmana, aceptada por gran parte de la investigación académica, sobre los orígenes del Corán. Y propone mirarlo como testigo insustituible de dinámicas socioreligiosas del Medio Oriente, particularmente procesos vividos por el cristianismo de los siglos V-VII, marcado por grupos diferenciados y en conflicto y la circulación de memorias y tradiciones sobre Jesús, no necesariamente ancladas en el Nuevo Testamento.

Palabras clave: Corán, Jesús, Apócrifos, Cristianismo antiguo, Azora 19.

\section{THE EMERGENCE OF THE QUR'AN IN A TIME OF WARS FOR JESUS}

Abstract: The article discusses the Muslim traditional point of view, accepted by much of the academic research, about the origins of the Qur'an, and suggests consider it as an irreplaceable witness of Middle Eastern socio-religious dynamics, especially processes experienced by Christianity in 5th-7th centuries, with differentiated groups in conflict and the circulation of memories and traditions about Jesus, not necessarily based in the New Testament.

Keyboards: Qur'an, Jesus, Apocryphal texts, Ancient Christianity, Surah 19

Recibido: 15.06.2016 - Aceptado: 21.09.2016

\section{Correspondencia: Pedro Lima Vasconcellos}

Email: plvas@hotmail.com

Doctorado em Ciencias Sociales - Pontificia Universidad Católica de San Pablo (Brasil);

Post-Doctorado en Historia - Universidad Estadual de Campinas (Brasil)

Dirección institucional: Programa de Pós-Graduação em História.

Universidade Federal de Alagoas Rua Sonho Verde, s/n - Bairro Eucalipto 57606-100 -

Palmeira dos Índios - AL - Brasil. 


\section{Introdução ${ }^{1}$}

$\mathrm{P}$ roponho aqui uma questão, sem ter a pretensão de resolvê-la; apenas me pergunto como um adequado encaminhamento para ela abre possibilidades novas para a investigação historiográfica, referente aos desenvolvimentos do cristianismo e à emergência do islamismo nos séculos da chamada "Antiguidade tardia", no âmbito do Oriente Médio. A questão diz respeito ao surgimento do Corão. O caminho que proponho para o enfrentamento dela avança em três passos. Primeiramente trato de identificar o problema, encarando alguns preconceitos (no sentido etimológico do termo) e confusões de campos e competências que, a meu ver, têm dificultado mapear o conjunto de problemas nela envolvido, bem como equacioná-los adequadamente. Em seguida trato de sumarizar o que tem soado quase como um consenso acadêmico a respeito das origens do Corão, que as relaciona de maneira direta, e praticamente exclusiva, à atividade profética de Muhammad numa Arábia supostamente isolada do restante do Oriente Médio. A colocação dessa perspectiva de análise em xeque, apontada por investigações mais recentes, permite tomar o Corão como produto que, em seu emergir, interage com movimentos socioculturais presentes no ambiente de seu nascedouro, dentro do qual destaco um complexo panorama de grupos e tradições referidas a Jesus. A abordagem desse cenário, que constitui meu terceiro e último passo nesse artigo, é aqui proposta a partir de uma rápida leitura de uma página do Corão, os primeiros quarenta versículos da sura 19, dos quais apenas alguns aspectos, pertinentes ao que pretendo desenvolver, serão destacados.

\section{O problema}

Começo com um postulado que pode ser formulado da seguinte maneira: o Corão tem sido interpretado à luz de critérios estabelecidos posteriormente à sua confecção, por exegetas e teólogos muçulmanos, no marco de um islã com algum grau de institucionalização; cabe entendê-lo também à luz do cenário que

$1 \quad$ Na base deste artigo está conferência pronunciada pelo autor no Seminário “A Antiguidade Tardia e as Matrizes do Corão", realizado aos 23 de novembro de 2015 no Instituto de Filosofia e Ciências Humanas da Universidade Estadual de Campinas (UNICAMP), Brasil.

2 Trata-se de um conceito, assumido por Brown (2012), que pretende assinalar as continuidades, em termos socioculturais, entre os tempos finais do domínio romano sobre o Mediterrâneo ocidental e aqueles que costumam ser tomados como os primórdios da Idade Média. 
o viu nascer. Movimento similar vem sendo feito, no campo da investigação das escrituras judaica e cristã, nos últimos dois séculos, no bojo e na esteira do que tem sido genericamente denominado "método histórico-crítico". Para ficar num exemplo, tratou-se de passar da leitura, marcada pela dogmática e condicionamentos institucionais cristãos, de uma carta aos romanos tal qual entendida por Agostinho, por Lutero ou pelo concílio de Trento, para uma abordagem que o toma por um "não-cristão", "um judeu radical", inserido nos enredos apocalípticos e outros movimentos da religião de Israel na alvorada de nossa era, prévios à destruição de Jerusalém, num mundo marcado tanto pela violência da política romana como pelos traços que genericamente podem ser denominados helenistas. Sem que com isso a pergunta pelo Paulo de Agostinho, ou o de Lutero, deixe de ter relevância; muito pelo contrário: distinguir o Paulo de seu tempo daquelas concepções que dele e de sua obra se desenvolveram em outros contextos abre inúmeras possiblidades, antes inusitadas, de investigação sobre uma personagem assim marcante.

Analogamente, abordar o Corão não na (legítima) perspectiva de suas inscrições em meio ao mundo que ele decisivamente contribuiu para fundar, mas naquela, não menos necessária, de sua gênese histórica e cultural, permite vê-lo como testemunha importante de trajetórias médio-orientais nos tempos da Antiguidade tardia, em que, por exemplo, confluem tradições, livros e temas que ganharam e desenvolveram vida em meio a trajetórias do que, grosso modo, denominamos cristianismo, para não mencionar outras matrizes religiosas e culturais ${ }^{3}$. Tanto o Corão pode ser melhor compreendido, quanto às motivações que terão estimulado a redação e a compilação de seus textos, como as referidas trajetórias eventualmente receberão uma abordagem mais qualificada, para além de caracterizações genéricas e adjetivas.

No entanto essa empreitada, além das dificuldades técnicas que comporta, vem carregada de outras, de variada ordem. Uma, que pareceria prosaica, é efetiva: o Corão costuma ser visto como um produto do primeiro medievo, quando aparece na história do Oriente Médio e daí se desenvolve; os historiadores, portanto, quando o abordam, tenderão a compreendê-lo no bojo da expansão do islã, no Oriente Médio, no norte da África, na Península Ibérica, em tempos medievais. Assim tomado, este livro pouco teria a dizer sobre as temáticas perseguidas por quem se dedica à história do cristianismo naquelas paragens médio-orientais, naqueles tempos marcados, digamos,

3 "Aqueles que estudam as tradições marginais cristãs e judaicas nos séculos VI e VII têm percebido recentemente que o período formativo do islã é também para eles uma mina de ouro" (Ferrín, 2013, 11). 
pelas controvérsias, que ganhavam as ruas, os trabalhos e os dias, nos tempos dos concílios de Éfeso e de Calcedônia, em meados do século V, e nos anos subsequentes. Enfim, para uns (estudiosos da Antiguidade) e outros (medievalistas), o Corão, mais que uma expressão da Antiguidade tardia, por emergir nos primórdios da Idade Média deve ser abordado a partir dessa conjuntura, nas histórias que faz junto às gentes alcançadas pelo islamismo. É preciso avançar para além dessa divisão arbitrária e artificial: além das histórias que o Corão enquanto tal começa a fazer a partir do século VIII, urge considerar aquelas que o fizeram, o que nos remete para tempos anteriores e conjunturas em que expressões cristãs distintas, eventualmente em conflito umas com outras, são marcantes e decisivas.

Este desafio se articula a outro, de muito maior gravidade e extensão: avançar pedindo licença à narrativa mítica a respeito das origens do Corão, sem com isso a desconsiderar em sua relevância eficaz; mas não simplesmente tomar a narrativa que ele enuncia como informação a respeito dos processos humanos, histórica e socialmente situados, dos quais o referido livro é resultado. A confusão entre uma coisa e outra é muito mais comum do que se poderia imaginar. A título de exemplo, tomo a seguinte apresentação:

o conteúdo sagrado do Alcorão [...] compreende uma série de revelações dadas a Maomé [...]. Elas foram transmitidas oralmente, em diversas circunstâncias [...] por intermédio do anjo Gabriel. Essas comunicações enviadas por Deus foram repetidas textual e publicamente por Maomé durante os 22 anos de seu ministério [...]. Portanto o Alcorão é as palavras de Deus, repetidas, sem erro, por seu "enviado" ou "mensageiro" (rasul), como ele é chamado no Alcorão, e como todo muçulmano deve crer (Peters, 2008, 47; o destaque é meu).

Peters não é adepto da fé muçulmana; diferentemente disso, foi durante muitos anosprestigiado professor de História das Religiões. Mas surpreende a absoluta concordância entre o que ele propõe como síntese sobre as origens do Corão e aquilo que, ele mesmo reconhece, "todo muçulmano deve crer". Do ponto de vista da Ciência da Religião e da história que esta crença islâmica a respeito do caráter único do Corão veio fazendo ao longo do tempo, nada a objetar: eis uma tarefa a que não se pode recusar; apenas não é ela com que ocupo aqui. Outra coisa é tomar um enunciado de fé como descrição de processos que têm a ver com dinâmicas socioculturais complexas; são eles que me ocupam aqui e nos congregam nessa oportunidade. 
Confundir aqui as competências e os propósitos pode revelar-se desastroso. Exatamente este nó tecido de confusões quanto a gêneros literários e intencionalidades precisa ser desfeito. E isso porque, talvez não de forma assim tão devotada, a grande maioria dos pesquisadores dedicados à obra corânica tem assumido os pressupostos da fé muçulmana a respeito de seu livro sagrado, transpondo-os, sem mais, para as bases de suas investigações, ou dedicando-se a defendê-los como fiáveis do ponto de vista da busca histórica. Será preciso tomar contato, mesmo que brevemente, com esse percurso já trilhado, identificando alguns de seus alcances e limites, bem como identificando impasses que exigem a busca de outras perspectivas.

\section{II. $O$ consenso acadêmico}

Alguns pesquisadores têm sugerido falar de um "paradigma Nöldeke"4, associado à figura do importante estudioso do Corão Theodor Nöldeke. Sua obra principal, surgida em 1860, com notáveis acréscimos e revisões, feitos por ele mesmo e por discípulos, continua a representar um marco, tendo estabelecido basicamente dois postulados: 1) o texto corânico que nos chegou é expressão da experiência de uma comunidade formada em torno de Muhammad e que com ele viveu duas fases distintas e decisivas, primeiramente em Meca (entre 610 e 622 de nosso calendário), depois em Medina (entre 622 e 632); 2) é possível e necessário estabelecer a cronologia das proclamações orais do profeta através do exame das suras e de sua classificação básica em mecanas ou medinenses, encontrada no próprio livro.

Tratando de desdobrá-los, Nöldeke distingue, para o período mecano, três etapas, e mais uma que abrange todo o período medinense. Sirvo-me da síntese seguinte, oferecida por Küng:

As suratas do primeiro período [Meca: 610-615] [...] apontam para a conversão dos infiéis ao Deus único, em que [sic] o sofrimento do inferno dos pecadores e a felicidade paradisíaca dos devotos. [...] As suratas são curtas, a linguagem dos versículos rítmicos é poética. [...]

Nas suratas do segundo período [Meca: 615-620] [...] os versículos e as suratas tornam-se mais longos e deixam de ter marcas comuns. [...] São sobretudo ilustrações da natureza e da história (em especial dos profetas mais antigos da Bíblia Hebraica) que apelam à confiança na onipotência

4 A expressão pode ser encontrada, por exemplo, em Dye $(2011,248)$. 
e na bondade de Deus.

As suratas do terceiro período [Meca 620-622] [...] são mais longas, transmitem uma menor inspiração e soam, por vezes, repetitivas.

As suratas do período de Medina (622-632, morte do profeta) estão orientadas para a consolidação da comunidade muçulmana e da atividade de Maomé, como seu chefe máximo espiritual e mundano, unanimemente reconhecido (Küng, 2010, 108; veja ainda Bell e Watt, 2006, 112-114)5.

A afirmação tradicional dá conta de um processo de oralidade-escrita,

mas longas seções das suras medinenses podem muito bem ter sido compostas por escrito: são formadas de longos períodos, têm dicção prosaica e maneira didática. Aquelas atribuídas [...] ao período mequense, ao contrário, têm muitos sinais de terem sido orais e até mesmo [...] de composição oral. A dicção é poética, de fato rimada; o estilo é emotivo, rápido; a expressão é breve, colorida, muitas vezes abrupta (Peters, 2008, 49).

Já a composição das suras de Medina apresenta um problema muito mais sério. As suras têm sabor de prosa e escrita, mais reflexão que intuição, todavia sabemos que Maomé carecia da habilidade de escrever, mais ainda de compor por escrito. As suras medinenses foram, talvez, ditadas, com cuidado e refletidamente. Esse processo explicaria o estilo e a dicção das últimas partes do Alcorão (Peters, 2008, 50).

Cabe ainda salientar que as suras medinenses estariam orientadas para a consolidação da comunidade muçulmana sob a liderança máxima de Muhammad.

Nöldeke está convencido de que "o Corão contém apenas peças originais" (citado por Dye, 2014, 2), ou seja, inegavelmente pronunciadas pelo

$5 \quad$ Segundo essa teoria, a sura 19, da qual tratarei logo adiante, seria do período mecano intermediário, tendo sido recitada pela primeira vez diante de cristãos da Abissínia (Nöldeke se apoia, em favor desta afirmação, em fontes tradicionais muçulmanas). Os v.34-40 poderiam ter sido adicionados mais tarde por Muhammad, "aproximadamente no fim do segundo ou no início do terceiro período [mecano] como um suplemento dogmático e polêmico aos versículos sobre Jesus"; a justificativa para essa avaliação são as diferenças, em termos de linguagem e de ritmo, entre estes versículos e os que os antecedem e sucedem (Nöldeke, 2013, 106). Nöldeke conclui assinalando que estaríamos diante da mais antiga (ou uma das mais antigas) referência corânica ao Novo Testamento e a figuras como João e Jesus, Zacarias e Maria (107). 
profeta. Os conteúdos delas eram conhecidos dos companheiros de Muhammad e estavam em grande parte redigidos quando da morte deste; talvez se encontrassem dispersos, recolhidos que estavam em materiais diversos; ficou a tarefa de apenas recolher e dispor o material dando-lhe uma organização, o que ocorreu, de forma definitiva, sob o califado de Uthman, pouco mais de vinte anos após a morte do profeta, ou seja, nos anos 650. Conclui-se daí que, sendo o Corão a expressão fiel e exata das palavras dele, não cabe estudá-lo com os métodos aplicados há tanto tempo, por exemplo, na abordagem dos processos que vão de Jesus à redação dos evangelhos presentes no Novo Testamento. Assim, se a crítica das formas serviu, no âmbito dos estudos neotestamentários, para identificar situações e processos em que e pelos quais as memorias a respeito de Jesus chegaram a ser redigidas nos evangelhos, no caso do Corão ela não é de qualquer serventia, pois o legado oral do Profeta não sofreu qualquer moldagem em sua transmissão. Ao ser colocado por escrito o Corão está sendo apenas recordado; no máximo um crítico poderia se perguntar pelas formas que Muhammad escolheu para expressar-se.

Angelika Neuwirth, em suas variadas iniciativas e publicações, é talvez a mais destacada e destemida pesquisadora contemporânea a sustentar a pertinência do "paradigma Nöldeke"; segundo ela, trata-se da hipótese mais plausível, embora impossível de ser provada. Sua ampla pesquisa "pressupõe" (as palavras são dela) que os dados básicos dos relatos tradicionais sobre a emergência do Corão são confiáveis: o texto redigido que nos chegou recolhe o que foi transmitido, qual seja, a coleção genuína das comunicações do Profeta tais como pronunciadas em Meca e Medina. Não cabe investigar a formação da mensagem corânica se por isso se entende interrogar-se sobre alguma dinâmica em seu desenvolvimento textual ou suspeitar de mudanças de orientação durante a fase de sua comunicação oral. A busca de fontes judaicas, cristãs ou de outra matriz é inócua, e deve ceder espaço ao entendimento do livro como um texto, um discurso com logica literária peculiar e agenda teológica própria.

No entanto, é o próprio Corão que parece endereçar seus leitores e ouvintes a certas tradições já conhecidas, indispensáveis ao entendimento de sua mensagem. Por exemplo, ele estimula a memória de narrativas bíblicas, e da lembrança delas desenvolve sua mensagem. O reconhecimento destas óbvias associações entre a literatura bíblica (incluídos aí todos aqueles títulos que costumam ser reunidos sob o qualificativo "apócrifos") e o que se lê no Corão de um lado, e a tendência de vincular os seus conteúdos à trajetória do profeta, por outro, acabaram por confluir na questão sobre de que formas ele teria tomado contato com a Bíblia e as tradições de cujo conjunto ela emerge: 
ele seria o eelo entre a Bíblia e o Corão, na medida em que teria tomado contato com judeus e cristãos. Mas é preciso questionar esse paradigma: a biografia de Muhammad que costuma ser evocada não resulta daquilo que a primeira comunidade muçulmana recordava, mas do que intérpretes muçulmanos desenvolveram em vistas a explicar o Corão; a narrativa da trajetória dele é, já ela mesma, um guia exegético para o livro. Há que se pensar no livro como tal, para além de seu suposto (e único!) inspirador, que, para além de ser a resposta tardia ao politeísmo da chamada Arábia pré-islâmica, teve os conteúdos que viriam a formá-lo concebidos em meio a um mundo de ideias e práticas religiosas, dinâmicas sociais e enfrentamentos políticos neste Oriente Médio de variados judaísmos e cristianismos, concílios, perseguições, debates, e guerras como as que naqueles tempos opunham persas a bizantinos; uma dinâmica sociorreligiosa complexa, ambientada num cenário que bebe de seculares influxos e inscrições.

\section{O Corão, produto da Antiguidade tardia}

Sugiro aqui apenas algumas possibilidades que a pesquisa mais recente, autônoma em relação ao "paradigma Nöldeke" vem indicando no tocante ao surgimento do Corão, em torno a dois eixos: a) a sura 19 e suas matrizes "cristãs"; b) o conteúdo mais geral do livro e o mundo da Antiguidade tardia médio-oriental.

\section{Um mosaico literário de Jesus}

Tomo como ponto de arranque a sura 19, em seus primeiros quarenta versículos. Ela suscita particular interesse, especialmente por parte de estudiosos ocidentais, dedicados aos desdobramentos do judaísmo rabínico ou às origens cristãs. Em especial os v.16-33 apresentam um fascinante retrato de Jesus para o qual confluem elementos tradicionais de variadas proveniências, o que faz supor vivazes trajetórias conduzindo, de memória em memória, de inscrição em inscrição, em reelaborações e transmissões, o perfil do filho de Maria a uma configuração peculiar, irredutível a qualquer uma anterior, mas dependente inevitável das matrizes que o tornaram possível. Mas é preciso considerar o conjunto maior. Tomemos contato com ele: 
${ }^{1}$ Caf, Ha, Yá, Ain, Sad. ${ }^{2}$ Lembrança da misericórdia de teu Senhor para com o Seu servo, Zacarias. ${ }^{3}$ Ao invocar, intimamente, seu Senhor, ${ }^{4}$ dizendo: "Ó Senhor meu, os meus ossos estão debilitados, o meu cabelo embranqueceu; mas nunca fui desventurado em minhas súplicas a Ti, ó Senhor meu! ${ }^{5}$ Em verdade, temo pelo que farão os meus parentes, depois da minha morte, visto que minha mulher é estéril. Agracia-me, de tua parte, com um sucessor! ${ }^{6}$ Que represente a mim e à família de Jacó; e faze, ó meu Senhor, com que esse seja complacente!" 7“'Ó Zacarias, alvissaramos-te o nascimento de uma criança, cujo nome será Yahia [João]. Nunca denominamos, assim, ninguém antes dele". ${ }^{8}$ Disse: "Ó Senhor meu, como poderei ter um filho, uma vez que minha mulher é estéril e eu cheguei à senilidade?" ${ }^{9}$ Respondeu-lhe: "Assim será! Disse teu Senhor: Isso Me é fácil, visto que te criei antes mesmo de nada seres". ${ }^{10}$ "Suplicou: Ó Senhor meu, faze-me um sinal!" Disse-lhe: "Teu sinal consistirá em que não poderás falar com ninguém durante três noites". " sinais, que glorificassem Deus, de manhã e à tarde. ${ }^{12}$ Ó Yahia, observa fervorosamente o Livro! E o agraciamos, na infância, com a sabedoria, ${ }^{13}$ assim como com as Nossas clemência e pureza, e foi devoto, ${ }^{14} \mathrm{e}$ piedoso para com seus pais, e jamais foi arrogante ou rebelde. ${ }^{15} \mathrm{~A}$ paz esteve com ele desde o dia em que nasceu, no dia em que morreu e estará no dia em que for ressuscitado. ${ }^{16} \mathrm{E}$ lembra Maria, no Livro, a qual se separou de sua família, indo para um local que dava para o leste. ${ }^{17} \mathrm{E}$ colocou uma cortina para ocultar-se dela (da família), e lhe enviamos o Nosso Espírito, que lhe apareceu personificado, como um homem perfeito. ${ }^{18}$ Disse-lhe ela: "Guardo-me de ti no Clemente, se é que temes a Deus". ${ }^{19}$ Explicou-lhe: "Sou tão-somente o mensageiro do teu Senhor, para agraciar-te com um filho imaculado". ${ }^{20}$ Disse-lhe: "Como poderei ter um filho, se nenhum homem me tocou e jamais deixei de ser casta?" ${ }^{21}$ Disselhe: "Assim será! Teu Senhor disse: Isso Me é fácil! E faremos disso um sinal para os homens, e será uma prova de Nossa misericórdia”. E foi uma ordem inexorável. ${ }^{22}$ Então ela o concebeu e se retirou, levando-o a um lugar distante, afastado. ${ }^{23}$ As dores do parto a constrangeram a refugiar-se junto a uma palmeira. Disse: "Oxalá eu tivesse morrido antes disto, ficando completamente esquecida". ${ }^{24}$ Porém, chamou-a uma voz, junto a ela: "Não te atormentes, porque teu Senhor fez correr um riacho a teus pés! ${ }^{25} \mathrm{E}$ sacode o tronco da palmeira, de onde cairão sobre ti frutos maduros e frescos. ${ }^{26}$ Come, pois, bebe e consola-te; e se vires 
algum humano, faze-o saber que fizeste um voto de jejum ao Clemente, e que hoje não poderás falar com pessoa alguma". ${ }^{27}$ Regressou ao seu povo levando-o nos braços. E lhes disseram: "Ó Maria, eis que fizeste algo extraordinário! ${ }^{28} \mathrm{O}$ irmã de Aarão, teu pai jamais foi um homem do mal, nem tua mãe uma sem castidade!" ${ }^{29}$ Então ela lhes indicou que interrogassem o menino. Disseram: "Como falaremos a uma criança que

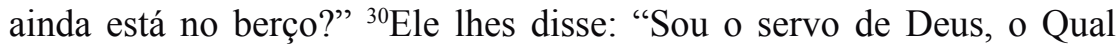
me concedeu o Livro e me designou como profeta. ${ }^{31} \mathrm{Fez}-\mathrm{me}$ abençoado, onde quer que eu esteja, e me encomendou a oração e o zakat enquanto eu viver. ${ }^{32} \mathrm{E}$ me fez piedoso para com a minha mãe, não permitindo que eu seja arrogante ou desanimado. ${ }^{33} \mathrm{~A}$ paz está comigo, desde o dia em que nasci; estará comigo no dia em que eu morrer, bem como no dia em que eu for ressuscitado". ${ }^{34}$ Este é Jesus, filho de Maria; é a pura verdade, da qual duvidam. ${ }^{35} \mathrm{E}$ inadmissível que Deus tenha tido um filho. Glorificado seja! quando decide uma coisa, basta-lhe dizer:” Seja!", e é. ${ }^{36}$ E Deus é o meu Senhor e vosso. Adorai-O, pois! Esta é a senda reta. ${ }^{37}$ Porém, as seitas discordaram entre si. Ai daqueles que não creem no comparecimento ao grande dia! ${ }^{38}$ Quão ouvintes e quão videntes serão, no dia em que comparecerem ante Nós! Porém, os iníquos estão, hoje, em um evidente erro. ${ }^{39} \mathrm{E}$ admoesta-os sobre o dia do lamento, quando a sentença for cumprida, enquanto estão negligentes e não creem. ${ }^{40} \mathrm{Em}$ verdade, Nós herdaremos a terra com todos os que nela estão e a Nós retornarão todos ${ }^{6}$.

$\mathrm{Na}$ verdade, se se considera o fragmento com um pouco de cuidado, não é difícil notar que praticamente nenhum elemento ou detalhe nele encontrado deixa de ecoar antigos textos, lugares venerados, debates de longa duração sobre delicadas e decisivas questões, crenças tão ardorosamente professadas como contestadas no universo cristão médio-oriental daqueles tempos. O que vai a seguir é apenas um rápido sumário a este respeito; não pretendo, nem de longe, esgotar a questão:

a) a estrutura geral do texto (até o v.21; quiçá até o 33), baseada na sequência pai Zacarias/filho João - mãe Maria/filho Jesus, repousa num eixo que remete ao Evangelho segundo Lucas, em seus dois primeiros capítulos, com ou sem a mediação do Diatessaron de Taciano, o que pode ser verificado também nos detalhes, nas suposições, omissões e correções que a sura parece estabelecer

6 A tradução destes versículos toma por base o texto preparado por Samir elHayek, com alguns ajustes em vistas a uma fidelidade maior ao original árabe. 
sobre esta tradição. E ainda: a concisão e mesmo lacunas e referências vagas encontradas no relato fazem pensar que a plateia para a qual ele foi pensado conhecia a narrativa evangélica, ou de alguma variante sua;

b) o texto também ecoa elementos importantes encontrados em livros, narrativas e/ou discursos que tinham presença significativa naquela época, embora sejam pouco conhecidos na atualidade; refiro-me às tradições sobre o nascimento de Jesus encontradas em textos tão distintos (hoje abrigados sob o qualificativo "apócrifos") como o Proto-evangelho de Tiago e o Evangelho de Bartolomeu(por exemplo, que Maria tenha dado à luz a seu filho num lugar ermo, e não em Belém; e que Jesus, recém-nascido, faça uso da palavra para apresentar-se a si mesmo);

c) o(s) redator(es) do texto têm notável conhecimento de tradições concernentes a Maria, quanto a símbolos a ela associados (palmeira, pedra), quanto à topografia de Jerusalém e cercanias a ela relacionada (o lugar do parto), em relação a monumentos a ela dedicados (igreja de Káthisma ${ }^{7}$ ), a liturgias em comemoração dela, e ainda no que diz respeito a controvérsias em torno da legitimidade de seu parto;

d) a conjugação entre palmeira e curso d'água no cenário do parto de que nasce Jesus sugere também um conhecimento de narrativas, de matriz grecoromana, concernentes a nascimentos de deuses, eventualmente reelaboradas em ambientes cristãos, algo de que é testemunha o chamado Evangelho do PseudoMateus, que, no entanto, situa esta cena no âmbito da viagem de Maria e seu filho, e ainda José, fugindo para o Egito;

e) no tocante especificamente à figura de Jesus, durante toda a sessão narrativa (v.16-33), o texto cuidadosamente se afasta de algumas de matrizes como o terceiro evangelho canônico e o Diatessaron: se de um lado acentua (na esteira do Proto-evangelho de Tiago) a concepção virginal por Maria e a legitimação do parto de Jesus (o que, obviamente, faz dele uma figura diferenciada), de outro apresenta este último apenas como "servo" e "profeta" de Deus, ao mesmo tempo que se nega categoricamente a seu "filho", situando-se, portanto,

$7 \quad$ Desta igreja, recentemente encontrada e submetida a averiguações de ordem arqueológica, destaco que terá sido construída em meados do século VI e dedicada à "mãe de Deus". No lugar do seu assento (para parir) constaria uma fonte de água, e em seu piso eram reproduzidas palmeiras. Muito provavelmente esse templo, convertido em local de culto muçulmano em fins do século VII, serviu de modelo para a construção do Domo da Rocha (Shoemaker, 2003, 11-39). 
em meio a um emaranhado de afirmações e negações a respeito dessa delicada questão, que já vinha fazendo correrem tinta e sangue há uns bons séculos, como o próprio texto reconhece: "as seitas discordaram a seu respeito" (v.37);

f) a expressão “irmã de Aarão", aplicada a Maria no v.28, longe de representar um engano, como tantos quiseram ver ao longo do tempo (como poderia ser a mãe de Jesus irmã do irmão de Moisés, personagem anterior a ela em mais de mil anos?), mostra conhecimento, no âmbito da redação deste escrito, de resultados daquilo que se costuma denominar "exegese tipológica", e eventualmente de sua prática; "do ponto de vista tipológico, que é o do Corão", a identificação entre as duas Marias "faz sentido, e dos bons" (Frye, 2004, 209);

g) as "letras enigmáticas" no início do fragmento, sugerem conhecimento da liturgia de igrejas cristãs siríacas (Dye, 2012, 62, n. 18). O mesmo se diga de seu gênero literário, a soghitha, que consistia num poema feito de estrofes e refrães (como parecem ser os v.15 e 33), bem como da alternância entre narração e diálogo, que põe em cena personagens bíblicas;

h) os v.34-40, que alguns analistas consideraram uma interpolação posterior ${ }^{8}$, adotam uma tonalidade abertamente polêmica, eindicam a passagem do terreno do mito para o da polêmica, dos tempos em que são elaborados. Eles ecoam (especialmente os primeiros quatro), velhas e sempre novas questões de ordem cristológica, responsáveis pela convocação de concílios desde pelo menos o século IV e por um sem-número de choques e truculências em várias paragens, o que o texto claramente conhece e deplora (v.37).

Ou seja, este fragmento da sura 19 se constitui num todo resultado da convergência (entre tantas outras possíveis) entre diversas tradições, detalhes, narrativas, símbolos e memórias que não necessariamente são coincidentes em todos os detalhes. Seu enraizamento nos meandros da antiguidade cristã médio-oriental é notável. Por outro lado, este conjunto, elaborado no manejo de tantos dados, fontes, informações, por vezes desencontradas e contrastantes, não é um pastiche em que os elementos apareceriam dispostos em desordem; pelo contrário, soa fortemente articulado, como o evidenciam principalmente os paralelos entre as sessões Zacarias/João e Maria/Jesus; mas também que aí se façam presentes tradições que remetem a uma igreja dedicada a Maria em

8 É a posição, por exemplo, de Nöldeke (veja nota 5) e de Dye (2012, 63-64). 
termos que ele não tem como assimilar (mãe de Deus). O talento redacional também não deve passar despercebido; a combinação, em poucos versículos (27-29) entre questionamento da honradez de Maria (eco do Proto-evangelho de Tiago), apresentação de seu filho no Templo (ressonância do texto lucano [via Diatessaron?]) e o denominado "milagre do berço" (a fala de Jesus bebê), é um dos bons exemplos nesse sentido. Outro detalhe a se destacar se refere à forma como o(s) redator(es) do fragmento o compõem: se na sessão Zacarias/ João é inegável a base lucana (através ou não de Taciano), na sessão Maria/ Jesus a composição se mostra muito mais complexa, ao assumir a mesma base e associá-la a tradições oriundas de outras matrizes. Há como que um "descolamento" frente a essa base de matriz lucana, e a figura de Maria ganha perfil diferenciado: se em Lucas ela assumia algum protagonismo (ao dar seu "sim" ao emissário divino, ou na visita que faz a Isabel e no Magnificat que profere), na sura 19 ela aparece muito mais vítima da intervenção divina e das acusações dos seus (e também beneficiária de alguma compensação pelos constrangimentos a que se vê submetida).

Há, portanto, uma síntese diferenciada que o fragmento em questão procura comunicar, e cujo teor não é tarefa deste momento averiguar; o que desejoreiterar é que o conjunto terá feito sentido ao seu primeiro público remetendo permanentemente a tradições bíblicas e extrabíblicas, habilmente articuladas, sugerindo que este pano-de-fundo de referências e temas era de domínio generalizado.

2. O Corão e os traços do cristianismo na Antiguidade tardia médio-oriental

Sendo a sura 19, em sua original unidade, eco de tantas vozes e escritos, concepções e práticas, memórias e tradições, mapear o universo em que eles poderão ter circulado e interagido se mostra um desafio. O problema, no entanto, se agiganta quando temos em conta que a sura é componente destacada de um livro, o Corão, cuja gênese em sua totalidade tem sido vinculada, tanto pela tradição religiosa que ele sustenta como por boa parte da pesquisa acadêmica, à vida e atividade do profeta do islã. Mas a tarefa é justamente a de escapar ao que já foi denominado "big-bang muhamádico", e essa é uma questão que passa longe de ser estritamente acadêmica e cujo enfrentamento não tem ficado livre, em alguns casos, de preconceitos e riscos. Meu propósito, no âmbito dela, se restringe ao que poderia denominar o elemento cristão presente em textos corânicos. Também aí existem matizações e esclarecimentos a serem

9 A expressão é de Ferrín $(2015,84)$. 
feitos, detalhes a serem precisados, nervuras a serem identificadas. Trata-se de mapear, o quanto possível, o caleidoscópio cristão no cenário do Oriente Médio nos últimos séculos da Antiguidade (cuja complexidade, em termos culturais e religiosos, ultrapassa enormemente o mais sofisticado quadro cristão que se possa delinear), bem como perguntar-me por quais caminhos e elos o Corão se vê enraizado nesse cenário. Isso implicará recolocar a pergunta pelas suas origens (e, por consequência, do próprio islã). Apenas aponto possibilidades.

Christoph Luxenberg (2007) é o pseudônimo de um intelectual cuja identidade não é conhecida, que, trabalhando particularmente em perspectiva filológica, insere o Corão num pano-de-fundo de fala e escrita siríaca (predominantes no Oriente Médio nos tempos da Antiguidade tardia), o que remete a um contexto cristão, pré-islâmico. Segundo ele, o Corão se desenvolveu a partir da Qeryana, um tipo de devocionário utilizado nas liturgias das igrejas siríacas. Partes importantes do que hoje é o Corão foram escritas nesta língua, e quando essa conjuntura é consideradapara a leitura delas muitas passagens acabam ganhando sentidos inusitados e maior clareza. A interpretação que o texto corânico foi ganhando no desenrolar da história islâmica considerou-o a partir do estabelecimento do texto em árabe, ignorando esse processo prévio, o que teria resultado em não poucos problemas para seu entendimento. Daí que o empenho de Luxenberg seja o de propor algo como uma retrotradução, já que a recuperação do pano-de-fundo original, qual seja, o ambiente de fala e escrita siríaca, é fundamental para o entendimento de tantas passagens do atual Corão, que de outra forma soam mesmo obscuras. Com isso a abordagem dos conteúdos que formariam o livro fica autonomizada frente às tendências hermenêuticas mais restritivas representadas pelos comentários dos primeiros exegetas muçulmanos. O que daí resulta, em vários momentos, é que se fica muito (mais) próximo de textos da tradição cristã (os poemas de Efrém, o sírio, por exemplo), ou nos deparamos com paráfrases de textos neotestamentários, especialmente em versões siríacas. ${ }^{10}$

Por esse caminho filológico, Luxenberg alarga para trás, para antes dos anos em que Muhammad teria vivido, o tempo dentro do qual deve ser pensado o processo de gestação dos materiais que formam o Corão. Já o estadunidense John Wansbrough o amplia também para frente. Em duas monografias publicadas no fimdos anos 1970 (2004; 2006), ele tratou de aplicar ao Corão e aos primeiros

10 Em relação à sura que tomo aqui como ilustração de meu argumento, Luxenberg $(2007,142)$ sugere que o v.24, em que se reproduz a fala do menino recém-nascido endereçada a sua mãe, deva ter outro teor: "Não te entristeças! Teu Senhor tornou legítimo teu parto!" 
testemunhos escritos no mundo do islã os procedimentos do já mencionado "método histórico-crítico". Atento a tendências teológicas distintas detectáveis nos textos, ocupa-se do ambiente judeu-cristão que ofereceu aos primeiros muçulmanos os conceitos e os modelos que fundavam seu itinerário religioso. E conclui que a elaboração do Corão acompanhou pelo menos um século e meio de trajetórias, distintas nas formas, crenças e práticas, de grupos afins mas diversos, que só ao final de mais cinquenta anos teriam definido, em suas grandes linhas, seu mito de origem e os princípios de sua presença enquanto identidade específica. Não cabe pensá-lo prévio ou alheio ao desenvolvimento histórico de comunidades e da literatura mais ampla produzida no interior delas; pelo contrário, sua redação acompanhou e repercutiu as vicissitudes vividas pelos diversos grupos que confluiriam naquilo que hoje chamamos islã. Tanto o Corão como os demais escritos surgidos nestaconjuntura devem ser avaliados à luz de seus respectivos gêneros literários e com a devida consideração a este específico Sitz im leben ${ }^{11}$, em suas múltiplas facetas.

Assim, mais decisivo que os lugares e o tempo específicos da vida de Muhammad é aquilo que Wansbrough denomina o "ambiente sectário". Ele vê as sementes do Islã e do Corão em argumentos e polêmicas que permeavam grupos monoteístas situados à margem das tradições religiosas majoritárias então existentes na Arábia, mas principalmente fora dela. Pouco distinguíveis inicialmente, de muitas outras, aos poucos vão convergindo e diferenciando-se. Se muitas vezes tem sido postulada a existência deste ou daquele grupo religioso com o qual Muhammad possa ter estabelecido contato, para Wansbrough a religião que mais tarde seria denominada Islã emerge como emergindo dos próprios círculos sectários.

Assim, o importante do que Wansbrough, de um lado, e Luxenberg, de outro, representam não são tanto os resultados a que suas pesquisas chegaram, até porque possuem alta dose de pioneirismo, ousadia e risco, mas o desafio que, cada qual a seu modo, ambos puseram, qual seja, o de compreender o islã dos primórdios e o Corão no âmbito de um ambiente mais alargado, que abrange o Oriente Médio para além da Arábia, supõe um cenário com marcadas presenças judaicas e cristãs, para além do que em geral se pensa fosse o politeísmo árabe; enfim, tomar o Corão como um produto da Antiguidade tardia médio-oriental, em seu complexo político, cultural, socioeconômico, religioso. Não é viável reduzir tudo a eventuais influências e contatos vividos pelo profeta Muhammad

11 Expressão alemã que literalmente pode ser traduzida por "lugar na vida", amplamente utilizada nos estudos bíblicos para designar o ambiente histórico e cultural específico em que um determinado texto terá emergido. 
para se compreender esse amplo e profundo enraizamento dos textos do Corão no mundo social e cultural que o viu nascer. Até porque os testemunhos escritos primordiais sobre a vida do profeta também bebem do mesmo caldo cultural e se situam no âmbito da literatura que ancora a formação de uma nova identidade religiosa, a muçulmana. Rompe-se, portanto, a verdadeira "camisa-de-força" que vinculava umbilicalmente à trajetória do Profeta os conteúdos estabelecidos no Corão que conhecemos; sai-se de um cenário definido apenas pelas areias do deserto árabe e se amplia olhar para alcançar o Oriente Médio em toda a sua complexidade; mergulha-se num universo saturado de ideias, instituições e valores de tantas tradições religiosas: o Corão em seu nascedouro, e o islã nascente não se entendem, senão em intercâmbio com as diversas facetas desse mundo, em que mercadores e monges, exilados e dissidentes de toda ordem, peregrinos e milícias .

No interior dele se destaca, sem qualquer dúvida, uma verdadeira e dinâmica "nebulosa cristã", de múltiplas colorações e perfis. Sem a pretensão de mapeá-la em sua totalidade, cabe apenas indicar alguns traços que delineiem, por exemplo, um cenário, tanto em perspectiva sincrônica como diacrônica, que permita pensar como se chegou à configuração de uma passagem como Q 19:1-40. Há que se pensar que no ambiente que viria a ver a emergência do Corão viviam grupos que, referidos a Jesus, levavam a sério uma observância estrita da lei de Moisés, incluindo aí a práticas da circuncisão ea observância de regras e restrições de ordem alimentar, bem como leis relativas à pureza. Grupos que, tanto para Orígenes como para Jerônimo (entre outros), não eram judeus e não mereciam ser denominados cristãos. Entre eles se situam aqueles segmentos identificados nas fontes como ebionitas e/ou nazarenos (não se tem toda segurança de que essa dupla terminologia distinga grupos diferentes); mais intrigante ainda é constatar que o Corão justamente como "nazarenos" grupos referidos a Jesus aos quais ele se dirige, polemizando ou não. Talvez a esses grupos - ou a alguns deles - caiba a observação de Carlos Segovia (2015, 5253), que dá conta de cristãos (no sul da península arábica, por exemplo) que reconheciam a Jesus como o messias, mas não necessariamente daí concluíam sua filiação divina.

Mas esse caleidoscópio rico, variado e complexo constitutivo do mundo que viu emergir o Corão se sustentava também de outros parâmetros. Era um ambiente em que controvérsias religiosas ganham ruas e praças, bem como espaços nobres para doutas assembleias; seus cultores disputam favores imperiais (especialmente de Bizâncio e Pérsia) e exigem repressões aos respectivos adversários: guerras por Jesus e em seu nome. Tradições 
muçulmanas e cristãs sugerem ter Muhammad travado contato com um monge ariano (ou nestoriano), e dele recolhido as referências principais sobre Jesus que ecoam no Corão. O que indica muito mais, ou seja, a presença dessas e outras compreensões a respeito de Jesus naquele contexto, que não era apenas do futuro profeta do islã. Um Oriente Médio nos séculos V-VI em que se distinguiam (por vezes de forma confusa, em outras ocasiões de maneira mais evidente) cristãos nestorianos, cristãos monofisitas e aqueles que, eventualmente de forma pejorativa, eram denominados melquitas (ou seja vinculados aos ditames e políticas dos soberanos de Bizâncio) ${ }^{12}$, via alternarem-se momentos e situações de convivência entre eles com outras de tensões e violências explícitas, com anátemas e excomunhões mútuas. Mas é necessário, avançando para além dessas configurações mais gerais, considerar as margens e as periferias deste cenário, para encontrar, por exemplo, segmentos cristãos marcados por ideários escatológicos de corte apocalíptico, eventualmente milenarista. E, para além de denominações e posições doutrinárias, caberia mapear as práticas rituais típicas de um lugar como Jerusalém e arredores, as facções em tensão presentes numa mesma cidade ou região, diante do que emergiam (ou mesmo se contrapunham) tantas propostas de vida eremítica e monástica. Essa diversidade, por sua vez, precisa ser compreendida à luz do cenário religioso sincrético altamente complexo em que se insere, dentro do qual marcas do maniqueísmo e do zoroastrismo, bem como do rabinismo palestino e babilônico, não podem ser ignoradas. O Corão é fruto de todo esse mundo, denso, complicado, e tão pouco conhecido de nós.

12 Arianismo: corrente vinculada ao pensamento e ação do sacerdote Ario, de Alexandria, nos primórdios do século IV, que sustentava não ser Jesus da mesma essência divina de Deus, o Pai. Condenada no concílio de Niceia, teria longa vida nos séculos seguintes, fazendo-se presente em várias regiões em torno do Mediterrâneo. Nestorianismo: partidários do patriarca de Constantinopla, Nestório, deposto no concílio de Éfeso (431), não reconheciam que Maria pudesse ser denominada "mãe de Deus", pois no Jesus que viveu na terra coexistiriam o divino e o humano em duas pessoas e duas naturezas absolutamente distintas. Já os monofisitas (também conhecidos como "jacobitas, por conta da atividade do bispo Jacó, de Edessa [Síria]), sustentavam, em formas mais ou menos extremadas, que o divino de Jesus praticamente anulava o humano. O concílio de Calcedônia (451), realizado em meio a tensões e mortes decorrentes de assembleia ocorrida dois anos antes, estabeleceu a doutrina que sustentaria a posição dos melquitas (termo derivado do hebraico melek, rei) e a ortodoxia cristã posterior: a pessoa de Jesus subsiste em duas naturezas, a divina e a humana (para um panorama deste período turbulento ver Jenkins, 2013). 


\section{Conclusão}

Uma certa imagem de um islã emanado de si mesmo das areias do deserto árabe serve tanto para a consideração excepcional que este sistema religioso tem de si mesmo - análoga àquela que, durante séculos, o cristianismo cultivou a respeito de si próprio, negando sua matriz na religião de Israel - como à tendência histórica desenvolvida no Ocidente, marcada pela herança judeucristã, de encarar o islâmico como um ente alienígena. Por outro lado: situá-lo, com seu livro, no caldo histórico e cultural da Antiguidade tardia remeterá a um complexo e caleidoscópico universo, que um bispo monofisita de fins do século VII quis sintetizar com a expressão "pecados de Calcedônia", mas que ultrapassa em muito o que ela pode sugerir. As revoluções (as mal chamadas invasões ou conquistas) em cidades importantes do Oriente Médio do século VII respondiam, no pensar de tantos monges do deserto cujos escritos nos chegaram, aos males associados à institucionalização do cristianismo naquelas bandas: cada cidade romana invadida pelos persas lançava dúvida sobre as autoproclamadas ortodoxias. E o Corão, ao mesmo tempo como síntese da cultura mítico-religiosa próximo-oriental e articulada reação literária, política e religiosa a ortodoxias, institucionalizações e anátemas em curso, resulta deste longo tempo e amplo espaço convulsionado, o Mediterrâneo oriental dos anos 400-800. É a partir daí que ele passa a fazer suas histórias, entre eletrizantes e decisivas, fundando ortodoxias, institucionalizações e anátemas, e assim se inscreve em novos tempos e espaços, que alcançam o agora e também o aqui. É ao emergir desse universo com marcas judaico-cristãs decisivas que ele, "um documento do século VIII" vai deixando marcas e rastros aqui e ali, para o ser também do "duodécimo, do décimo-sétimo, do vigésimo século" (Smith, 1989, 20). E com vínculos profundos para além da Arábia, avançando tanto para a África Ocidental quanto rumo à Indonésia, imprimindo na Europa e nos Estados Unidos, como bem sabemos. E mesmo em cenários brasileiros, que pouco conhecemos, como o da Bahia da primeira metade do século XIX (Reis, 2003). 


\section{Referências Bibliográficas}

BERKEY, J. (2013). The formation of Islam: Religion and Society in the Near East, 600-1800. 9 ed., Cambridge: Cambridge University Press.

BELL, R. E WATT, W. M. (2006). Introducción al Corán. 2 ed., Madrid: Encuentro. BROWN, P. (2012). El mundo de la Antigüedad tardía. 3 ed., Madrid: Gredos.

DYE, G. (2011). "Le Coran et son contexte. Remarques sur un ouvrage récent", Oriens Christianus.95, 247-270.

DYE, G. (2012). "Lieux saints, partagés ou confisqués: aux sources de quelques péricopes coraniques (Q 19:16-33)”. In: Dépret, I. et Dye, G. (org.) Partagé du sacré: transferts, devotions mixtes, rivalités interconfessionelles. Bruxelles: Modulaires Européennes, 55-112.

DYE, G. (2014). "Su alcuni miti negli studi coranici” (Conferência na Università di Stranieri di Siena). 16p.https://www.academia.edu/6798469/Su_alcuni miti_negli_studi_coranici. Acesso em 23/09/2015.

EL-HAYEK, S. (trad.) O Alcorão sagrado. http://www.ebooksbrasil.org/adobeebook/ alcorao.pdf. Acesso em 17/04/15.

FRYE, N. (2004).O código dos códigos: a Bíblia e a literatura. São Paulo: Boitempo. GILLIOT, C. (2011). "Le Coran, production littéraire de l'Antiquité tardive ou Mahomet interprète dans le 'lectionnaire arabe' de la Mecque", Revue des mondes musulmans et de la Mediterranée, 129, 31-56.

GONZÁLEZ FERRÍN, E. (2013).La angustia de Abraham: los orígenes culturales del islam. Córdoba: Almuzara.

GONZÁLEZ FERRÍN, E. (2015). "La encrucijada del Islam (y de la Islamología)", Erebea, 5, 71-88.

JENKINS, P. (2013). Guerras santas: como 4 patriarcas, 3 rainhas e 2 imperadores decidiram em que os cristãos acreditariam pelos próximos 1500 anos. São Paulo: Leya.

HOYLAND, R. (2012).Early Islam as a Late Antique Religion. In: Johnson, S. F. (ed.) The Oxford Handbook of Late Antiquity.Oxford: Oxford University Press, 1053-1077.

KOESTER, H. (2005).Introdução ao Novo Testamento. São Paulo: Paulus, v.2.

KÜNG, H. (2010).Islão: presente, passado e futuro. Lisboa: Edições 70.

LUXENBERG, C. (2007).The Syro-Aramaic Reading of the Koran: a Contribution to the Decoding of the Language of the Koran. Berlin: Verlag Hans Schiler.

NEUWIRTH, A. (2003). "Qur'an and History - A Disputed Relationship: Some Reflections on Qur'anic History and History in the Qur'an", Journal of Qur'anic Studies, 5/1, 1-18.

NEUWIRTH, A. (2007). "Structural, linguistic and literary features". In: McAuliffe, J. D. (ed.) The Cambridge Companion to the Qur'an.Cambridge: Cambridge University Press, 97-113. 
NEUWIRTH, A. (2010). "Two faces of the Qur'an: Qur'an and Mushaf", Oral Tradition, 25/1, 141-156.

NEUWIRTH, A, SINAI, N. \& MARX, M. (ed.) (2010).The Qur'an in context. Historical and Literacy Investigations into the Qur'anic Milieu. Leiden/Boston: Brill.

NÖLDEKE, T. (2013). History of the Qur'an.Brill, Leiden (preparada por Wolfgang H. Behn a partir da quarta reimpressão da segunda edição do original alemão, com contribuições de Friedrich Schwally, Gotthelf Bergstrasser e Otto Pretzl).

PETERS, F. E. (2008).Os monoteístas: judeus, cristãos e muçulmanos (v.II: As palavras e a vontade de Deus). São Paulo: Contexto.

REIS, J.C. (2003). Rebelião escrava no Brasil. A história do levante dos malês em 1835. 3 ed., São Paulo: Companhia das Letras.

REYNOLDS, G. S. (2010). The Qur'an and Its Biblical Subtext. Abingdon/New York: Routledge.

REYNOLDS, G. S. (2011). "Le problème de la chronologie du Coran", Arabica. Leiden, 58, 477-502.

SEGOVIA, C. (2015). "En torno a Mahoma como mesías: una nueva mirada a las raíces cristianas del islam", Erebea, 5, 43-60.

SHOEMAKER, S. (2003). "Christmas in the Qur'an: the Qur'anic Account of Jesus' Nativity and Palestinian Local Tradition", Jerusalem Studies in Arabic and Islam, 28, 11-39.

SHOEMAKER, S. (2012). "Muhammad and the Qur'an". In: Johnson, S. F. (ed.) The Oxford Handbook of Late Antiquity.New York: Oxford University Press, 1078-1108.

SMITH, W. C. (1989). "The Study of Religionand the Study of Bible". In: Levering, Miriam (ed.) Rethinking Scripture.Essays from a Comparative Perspective. Albany: State University of New York Press, 18-28.

VASCONCELLOS, P. L. (2013). "Metodologia de estudos de 'escrituras' no campo da Ciência da Religião". In: Passos, João Décio e Usarski, Frank (ed.). Compêndio de Ciência da Religião.São Paulo: Paulus/Paulinas, 469-483.

WANSBROUGH, J. (2004).Quranic Studies: Sources and Methods of Scriptural Interpretation. Amherst: Prometheus (com ampliações a cargo de Andrew Rippin).

WANSBROUGH, J. (2006).The Sectarian Milieu: Content and Composition of Islamic Salvation History. Amherst: Prometheus (com ampliações a cargo de Gerald Hawting). 